\title{
Severity of postoperative cardiac surgery Patients: na Evolution Analysis According to TISS-28
}

\author{
Rita de Cássia Mello Guimarães ${ }^{1}$ \\ Eneida Rejane Rabelo² \\ Maria Antonieta Moraes ${ }^{3}$ \\ Karina Azzolin ${ }^{4}$
}

This study verified the daily TISS-28 score in the postoperative period of cardiac surgery at a cardiology intensive care unit. This cohort study included 55 postoperative cardiac surgery patients, who were sent to the intensive care unit to recover. Data were collected from patients' records with daily application of the TISS-28. The obtained data revealed that the average age of the population was 61.47 years \pm 12.12 years, $78.2 \%$ were male, $51.43 \%$ underwent valve repair surgery and $48.57 \%$ myocardial revascularization surgery. The severity index in the immediate postoperative period was $41.33 \pm 5.01$. The followup of patients using the TISS-28 evidenced a significant decrease in the index values up to the patients' discharge, averaging at $13.19 \pm 2.59$. The results indicate that immediate postoperative cardiac surgery patients are in severe conditions, hemodynamically unstable and classified in class III according to the TISS-28, though scores gradually decrease over time.

Descriptors: Severity of Illness Index; Intensive Care; Thoracic Surgery.

\footnotetext{
${ }^{1}$ RN, Cardiology Nursing Specialist, Hospital São Francisco, Santa Casa de Misericórdia de Porto Alegre, Brazil, e-mail: coordenadorapc@cardiologia.org.br.

${ }^{2}$ RN, Ph.D. in Biological Sciences, Hospital de Clínicas de Porto Alegre, Brazil. Adjunct Professor, Escola de Enfermagem, Universidade Federal do Rio Grande do Sul, Brazil. Faculty, Instituto de Cardiologia, Fundação Universitária de Cardiologia, Brazil. E-mail: rabelo@ portoweb.com.br.

${ }_{3}^{3}$ M.Sc. in Health Sciences, Faculty, Instituto de Cardiologia, Fundação Universitária de Cardiologia, Brazil, e-mail: antonieta_moraes@ uol.com.br.

${ }^{4}$ M.Sc. in Health Sciences, Faculty, Centro Universitário Metodista IPA, Brazil. Faculty, Instituto de Cardiologia, Fundação Universitária de Cardiologia, Brazil. E-mail: karina.azzolin@metodistadosul.edu.br.
}

Corresponding Author:

Rita de Cássia Mello Guimarães

Fundação Universitária de Cardiologia

Rua Princesa Isabel, 370

Bairro Santana

CEP: 90620-000 Porto Alegre, RS, Brasil

E-mail: : coordenadora-pc@cardiologia.org.br 


\section{Gravidade de pacientes em pós-operatório de cirurgia cardíaca: uma análise evolutiva segundo o TISS-28}

O objetivo deste estudo foi verificar o escore diário do TISS-28 no pós-operatório de cirurgia cardíaca, em uma unidade de terapia intensiva cardiológica. Como método foi usado o estudo de coorte, que incluiu 55 pacientes, em pós-operatório de cirurgia cardíaca, com indicação de recuperação em unidade de terapia intensiva (UTI). Os dados foram coletados em prontuário, com aplicação diária do TISS-28. Os dados obtidos mostraram que a média de idade da população era de $61,47 \pm 12,12,78,2 \%$ do sexo masculino, 51,43\% realizaram cirurgia de correção valvar e 48,57\% realizaram cirurgia de revascularização do miocárdio. Ainda, o índice de gravidade no pós-operatório imediato foi $41,33 \pm 5,01$. O acompanhamento dos pacientes pelo TISS-28 demonstrou

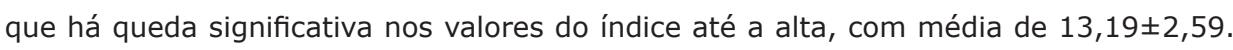
Pode-se concluir que os resultados indicam que os pacientes em pós-operatório imediato de cirurgia cardíaca são graves e hemodinamicamente instáveis, classificados em classe III pelo TISS-28, porém, a pontuação reduz gradualmente com o passar do pósoperatório.

Descritores: Índice de Gravidade de Doença; Cuidados Intensivos; Cirurgia Torácica.

\section{Gravedad de pacientes de cirugía cardíaca: un análisis evolutivo según el TISS-28}

El objetivo de este estudio fue verificar el puntaje diario del TISS-28 en el posoperatorio de cirugía cardíaca, en una unidad de terapia intensiva cardiológica. Como método fue usado el estudio de coorte, que incluyó 55 pacientes, en posoperatorio de cirugía cardíaca, con indicación de recuperación en unidad de terapia intensiva (UTI). Los datos fueron recolectados en ficha, con aplicación diaria del TISS-28. Los datos obtenidos mostraron que el promedio de edad de la población era de $61,47 \pm 12,12,78,2 \%$ del sexo masculino, 51,43\% realizaron cirugía de corrección de valvular y 48,57\% realizaron cirugía de revascularización del miocardio. También, el índice de gravedad en el posoperatorio inmediato fue $41,33 \pm 5,01$. El acompañamiento de los pacientes por el TISS-28 demostró que hay una disminución significativa en los valores del índice hasta el alta, con promedio de $13,19 \pm 2,59$. Se puede concluir que los resultados indican que los pacientes en posoperatorio inmediato de cirugía cardíaca son graves y hemodinámicamente inestables, clasificados en clase III por el TISS-28, sin embargo, la puntuación se reduce gradualmente con el pasar del posoperatorio.

Descriptores: Índice de Severidad de la Enfermedad; Cuidados Intensivos; Cirugía Torácica.

\section{Introduction}

Intensive Care Units (ICUs) make up approximately $20 \%$ of total hospital costs. The issue of the ICUs' financial costs required a critical evaluation of the care delivered at these units and the establishment of better indices or indicators that determine the severity of patients, supporting the need for intensive care or $\operatorname{not}^{(1)}$.

On the one hand, there is no doubt that the ICU is the appropriate unit for the treatment of severe but recoverable patients and, on the other hand, identifying which patients need intensive care and analyzing their real conditions has become feasible due to the development of specific indices or measurement systems and prognostic methods for this purpose ${ }^{(2)}$. Indices of severity are defined as numerical classifications related to patients' characteristics, which provide means to assess mortality risks. These indices can also be used 
to monitor the development of patients' conditions, allocate resources and compare services with similar characteristics ${ }^{(3-5)}$.

Amongst the available indices, the Therapeutic Intervention Scoring System (TISS) has been useful to classify patients in ICUs. This index is based on invasive or monitoring methods and quantifies the number of therapeutic interventions performed on patients 24 hours per day after surgery. The TISS also foresees needs related to nursing, allowing for proper personnel dimensioning according to the complexity of care required by patients and permits estimating costs and income. Thus, it is an technical-administrative tool to evaluate the care process ${ }^{(6-8)}$.

The TISS was reformulated through the years and its last version, known as TISS-28, contains 28 items. After using this version to record many observed nursing activities in the ICU, we concluded that one item is equivalent to 10.6 minutes of the time a nursing professional spends on direct care delivery to a patient. The TISS-28 was translated to Portuguese and validated in 2000 as an instrument to measure the severity of patients in $\operatorname{ICUs}^{(9)}$.

Some studies in this field used the TISS 76 and the TISS 28 and demonstrated the utility of this system in the classification of patients' severity, both isolated and in comparative analyses with different indices. However, the use of the TISS-28 to characterize the development of patients in ICUs has been little explored ${ }^{(10)}$.

This context evidenced the need to implement a severity score that permits improving the decisionmaking process related to discharging or keeping patients in the ICU, delivering appropriate care, identifying or not the need to provide intermediary care to postoperative cardiac surgery patients through established numerical parameters.

In this perspective, using the TISS-28, this study measured the severity score of postoperative cardiac surgery patients in a cardiology intensive therapy unit, upon patients' discharge, and evaluated the association between the type of surgery, hospital permanence, postoperative complications and patients' severity.

\section{Method}

This prospective cohort study was conducted in the ICU of a hospital specialized in cardiology in Rio Grande do Sul, Brazil.

The study population was composed of patients of both genders, 18 years or older, during the postoperative period of cardiac surgery, who were recommended to recover in the ICU (coronary artery bypass with and without cardiopulmonary bypass and valve corrections) during the data collection period. Sample size was calculated for the desired range of 5 and confidence interval of $99 \%$ in 55 patients. The analyzed variables were: TISS-28, gender, age, type of cardiac surgery, associated comorbidities, postoperative complications, permanence and readmission in the ICU. TISS-28 scores are ranked as follows: class I - physiologically stable patients requiring prophylactic observation, score between 0 and 19 points; class II - patients requiring intensive care and continuous monitoring, score between 20 and 34 points; class III - severe and hemodynamically unstable patients, score between 35 and 60 points. In class IV, scores higher than 60 indicate that special and continuous care is needed(11).

Data collection was carried out through a tool developed for this study, divided in 3 parts: the first part contains sociodemographic data retrieved from patients records. The second contains clinical-therapeutic data, such as comorbidities, obtained from anesthetic forms, and postoperative complications collected from medical records. The third part is composed of the TISS-28, which the researcher (RCMG) applied daily in the immediate postoperative period and until patients were discharged from the ICU. The first six hours after patients' admittance to the ICU were considered immediate postoperative. This criterion $^{(12)}$ was used because it is an essential period in patients' stabilization process.

Data were collected at $6 \mathrm{pm}$ and information concerning the previous 24 hours was taken into account with a view to standardization. Evaluations were carried out on the first and last days in the ICU, that is, upon admission and discharge, even if the permanence was less than 24 hours.

The TISS-28 was recorded daily from the first to the eighth day and on the day of discharge whenever patients remained in the ICU longer than 8 days. This criterion was adopted considering twice the average permanence in ICUs, which is estimated at four days.

In cases of readmission to the ICU, the TISS-28 was recorded on the day patients returned to the unit for later comparison to the index of the first discharge.

Because data were collected in patients' files and no interventions were implemented, a commitment form authorizing the use of data was used. The Research Ethics Committee from the studied facility approved the project. 


\section{Statistical Analysis}

The continuous variables were presented with mean and standard deviation and categorical variables with absolute and relative frequencies. To compare means between groups, Student's t test and ANOVA with Tukey's Post Hoc test were used. To compare means between different moments in time, Student's paired t test was used. To assess correlations between continuous variables, Pearson's correlation coefficient was used. Data were analyzed with statistical software SPSS $12.0 ; \mathrm{p}<0.05$ was considered significant.

\section{Results}

Of the 55 patients admitted to the surgical ICU, 3 were readmitted for intensive care, totaling 58 admissions. A total of 238 evaluations were recorded through TISS-28 in the period.

The average age of the patients was $61.47 \pm$ 12.12, varying between 20 and 85 years, 43 (78.2\%) were male and 35 (63.65\%) were from Porto Alegre, RS, Brazil. The group's characteristics are summarized in Table 1.

Table 1 - Group's general characteristics. Porto Alegre, RS, Brazil, 2006

\begin{tabular}{lc}
\hline \multicolumn{1}{c}{ Characteristics } & $\mathbf{N}=55$ \\
\hline Male & $43(78.2)$ \\
Age (in years) & $61.47 \pm 12.12$ \\
Body mass index $\left(\mathrm{kg} / \mathrm{m}^{2}\right)$ & $27.04 \pm 4.85$ \\
Presence of comorbidities* & \\
Systemic blood pressure & $34(61.8)$ \\
Smoking & $25(45.5)$ \\
Ischemic cardiopathy & $21(38.2)$ \\
Prior cardiac surgery & $15(27.3)$ \\
Dyslipidemia & $11(20)$ \\
Diabetes mellitus & $9(16.4)$ \\
Obesity & $8(14.5)$ \\
Chronic obstructive pulmonary disease & $7(12.7)$ \\
Kidney failure & $7(12.7)$ \\
Prior stroke & $3(5.5)$ \\
Dilated cardiomyopathy & $1(1.8)$ \\
Alcoholism & $1(1.8)$ \\
Left ventricular dysfunction EF<40\% & $6(10.9)$ \\
CABG & $28(50.9)$ \\
With cardiopulmonary bypass & $10(32.7)$ \\
Without cardiopulmonary bypass & $18(18.2)$ \\
Aortic & $27(49.1)$ \\
Mitral & $16(29.1)$ \\
\hline
\end{tabular}

Continuous variables presented with average + standard deviation. Categorical variables are presented with $\mathrm{n}(\%)$. $E F=$ ejection fraction *refers to the presence of the comorbidities listed below.
Table 2 shows the average TISS- 28 score during the patients' hospitalization in the ICU. The data regarding the first day (TISS-1) correspond to the immediate postoperative average (until the sixth hour). Similarly, scores related to discharge correspond to the average of the patients' last six hours in the ICU.

Table 2 - Averages of TISS-28 and number of patients from the $1^{\text {st }}$ to the $8^{\text {th }}$ days in the ICU. Porto Alegre, RS, Brazil, 2006

\begin{tabular}{cccc}
\hline TISS & $\mathbf{N}$ & Score & $\mathbf{p}^{* *}$ \\
\hline 1 & 55 & $41.33 \pm 5.01$ & \\
2 & 55 & $30.56 \pm 7.06$ & $<0.001$ \\
3 & 55 & $19.53 \pm 10.17$ & \\
4 & 25 & $19.48 \pm 8.79$ & \\
5 & 16 & $18.25 \pm 6.66$ & \\
6 & 10 & $16.80 \pm 4.44$ & \\
7 & 9 & $14.33 \pm 5.07$ & \\
8 & 5 & $13.80 \pm 3.96$ & \\
TISS discharge & $54^{*}$ & $13.19 \pm 2.59$ & $<0.001$
\end{tabular}

Continuous variables presented with average + standard deviation. TISS: therapeutic intervention scoring system. $\mathrm{N}$ : number of patients. $*_{1} 1$ death excluded **to compare averages of TISS 1 , TISS 3 and TISS discharge, Student's paired t test was used.

According to Table 2, the TISS-28 to evaluate patients' severity varied from a minimum of 16.78 to a maximum of 46.67 points, with a total average of $27.07 \pm 4.66$ points. The average was $41.33 \pm 5.01$ in the immediate postoperative period (IPO), and $13.19 \pm$ 2.59 in TISS discharge. These findings are statistically significant, $\mathrm{p}<0.001$.

The average of TISS-28 in the IPO among patients previously submitted to cardiac surgery was $45.93 \pm$ 3.55 , compared to $39.60 \pm 4.36$ for those who were not, which are statistically significant scores, $\mathrm{p}<0.001$.

Analyzing the time patients spent in the ICU, the results revealed a median of 2 days (percentiles 25 and 75 of 2-4). The number of patients admitted during this period decreased from 55 to 5 (9.09\%) patients from the first to the eighth days.

The patients who presented the highest average scores in the $3^{\text {rd }}$ and $4^{\text {th }}$ days stayed longer in the ICU. This period was chosen because discharge from the surgical ICU occurs around the $3^{\text {rd }}$ and $4^{\text {th }}$ days and also because the average TISS is usually significantly lower in this period, with a strong correlation, $r=0.525$ 
and $r=0.507$, respectively $(p=0.002)$. Average ICU permanence for those who underwent aortic or mitral valve replacement was $4.63 \pm 3.07$ days and $2.27 \pm$ 0.65 , respectively. This difference between the groups was statistically significant ( $p=0.0019)$. There was no significant difference in permanence, TISS-28 score in the IPO and upon discharge when the groups of aortic valve replacement, mitral valve replacement and CABG were compared.

The complications considered in this study were those that occurred in the first 48 hours of admission into the ICU and cardiac arrhythmia (45.5\%) was the most prevalent.

Patients who presented some kind of complication in the IPO remained an average of $4.56 \pm 2.64$ days in the ICU, compared to $2.33 \pm 0.84$ days among those that did not present any complications, with a statistically significant difference for permanence and TISS-28 (43.24 \pm 4.65 versus $39.73 \pm 4.79), p<0.001$ and $\mathrm{p}=0.008$, respectively.

When the development of TISS-28 was analyzed for patients who presented complications on the first, second and third days postoperative, the TISS scores were significantly higher when compared to the scores of those who had no complications, $p<0.001$. After this period, the sample size was reduced to make comparisons.

The study's sample size was 55 patients and 33 of these were readmitted to the ICU in the first 48 hours after being discharged. They presented an average TISS28 score appropriate at discharge, that is, they were classified in class $\mathrm{I}$, which does not require intensive care. However, these 33 patients presented scores compatible to classes II and III, which require intensive care, at the time of readmission. There was one death among the readmissions in the first 24 hours in the ICU.

\section{Discussion}

There was a predominance of males older than 60 years, whose most relevant comorbidities were systemic blood pressure, smoking and ischemic cardiomyopathy in this cohort of 55 patients. This study revealed similar results to those of national and international studies ${ }^{(13-14)}$ regarding gender, age and clinical data, most relevant comorbidities, and predominance of the male gender and smoking. These findings confirm that longevity, associated with preexisting conditions, increases the odds of health problems such as cardiovascular diseases.

With regard to the severity of patients measured by the TISS-28, the obtained average score was lower than the score found in a similar study conducted in post-CABG $(27.07 \pm 4.66$ versus $38.6 \pm 9.7)$, in which the TISS-28 score was carried out after the first 24 hours, not taking into account the IPO. However, the average in IPO was similar $(41.33 \pm 5.01$ versus $38.6 \pm 9.7)$ and the same occurred for time of permanence ${ }^{(12)}$. Comparing the TISS-28 average score of this study with another study carried out in a general clinic ICU, the TISS-28 average scores were higher in postoperative cardiac surgery (27.07 vs. 21.9 ). It is believed that this difference is due to the diversity of the population in general ICUs and the severity of patients in postoperative cardiac surgery, who require several therapeutic interventions ${ }^{(15)}$.

The average time of permanence in this study was 2 days, which is not compatible with another study carried out in a general ICU, which found an average of 8 days $^{(16)}$.

The high TISS-28 score on the $3^{\text {rd }}$ and $4^{\text {th }}$ days after surgery was associated with longer permanence, because patients are usually in conditions to be discharged in this period, and those who still require complex interventions, adding points to the score, probably experienced complications in the postoperative period.

There was a significant number of patients who had complications in the postoperative period (45.5\%) and the average TISS-28 of patients with complications was significantly higher when compared to those who did not have complications after surgery (43.24 versus 39.73 ). Based on the premise that more severe patients are subject to more therapeutic interventions, the TISS-28 scores reflected the patients' worsening clinical conditions based on the number of therapeutic interventions.

\section{Conclusion}

This study leads to the conclusion that immediate postoperative cardiac surgery patients are severe and hemodynamically unstable, classified in class III by the TISS-28, however, the score gradually reduces over time. Patients who obtained high TISS scores between the $3^{\text {rd }}$ and $4^{\text {th }}$ days after surgery had a higher incidence of complications and longer permanence, though the score showed no significant differences in the type of surgery performed. Therefore, this study permitted evaluating the use of the care measurement instrument applied to postoperative cardiac surgery patients and the results revealed that the TISS-28 is a safe scale, easy to use and a source of important information when one aims to improve quality of care, optimize resources and reduce costs of intensive care. 


\section{References}

1. Queijo AF, Padilha KG. Instrumento de medida da carga de trabalho de enfermagem em unidade de terapia intensiva: Nursing Activies Score (NAS). Rev Paul Enferm 2004; 23(2):114-22.

2. Rocco JR Escores Prognósticos em Terapia Intensiva. In: David CM, Goldwasser R, Nácul FE. Medicina Intensiva: diagnóstico e tratamento. Rio de Janeiro (RJ): Revinter, 1997; p 308- 310

3. Cullen DJ, Keene R, Waternaux C, Peterson H. Objective, Quantitative Measurement of Severity of Illness in Critically ill Patiets. Crit Care Med 1984 March; 2(3):155-60.

4. Livianu J, Anção MS, Andrei AM, Faria LS. Índices Prognósticos em Unidade de Terapia Intensiva. In: Knobel E. Condutas no Paciente Grave. São Paulo (SP): Atheneu; 1998. p.1333-61.

5. Índices de Gravidade na Atualidade. In: $6^{\circ}$ Congresso Paulista de Terapia Intensiva; 1996; São Paulo, 22-25 de maio. São Paulo: SOPATI, 1996; p.5-6.

6. Miranda DR, Rijk AP, Schaufeh W. Simplified Therapeutic Intervention Scoring System: the TISS-28 items-results from a multicenter study. Crit Care Med 1996; 24(1):64-73.

7. Cullen DJ, Civetta JM, Briggs BA, Ferrara LC. Therapeutic Intervention Scoring System: a method for quantitative comparison of patient care. Crit Care Med 1974; 2(2):57-60.

8. Keene AR, Cullen DJ. Therapeutic Intervention Scoring System: update 1983. Crit Care Med 1983 January; 1(1):1-3.

9. Nunes B. Tradução para o Português e Validação de um Instrumento de Medida de Gravidade na UTI: TISS-28 Therapeutic Intervention Scoring System [Dissertação]. São Paulo (SP): Escola de Enfermagem de São Paulo/ USP; 2000.
10. Nascimento EFA. Caracterização dos pacientes adultos internados em unidade de terapia intensiva: análise da gravidade segundo SAPS II e TISS-28 [Tese]. São Paulo (SP): Escola de Enfermagem USP; 2002.

11. Elias ACGP, Masuto T, Cardoso LTQ, Grion CMC. Aplicação do sistema de pontuação de intervenções terapêuticas (TISS-28) em Unidade de Terapia Intensiva para avaliação da gravidade do paciente. Rev Latino-am Enfermagem 2006;14(3):324-9.

12. Velásquez LDS, Sánches MER, Sánches LC, Carpinteiro AC, Silva L O, Rivera LCB. Intervención Terapéutica en el Enfermo con Cirugía Cardiaca. Tres sistemas de calificación. Rev Med Inst Mex Seguro Soc 2002; 40(1):53-60.

13. Feier FH, Santanna RT, Garcia E, Bacco FW, Pereira E, Santos $M F$, et al. Modificações no perfil do paciente submetido a operação de revascularização do miocárdio. Rev Bras Cir Cardiovasc 2005; 20(2):68-75.

14. Bastos PG, Wagner DP. Application of the APACHE III prognostic system in Brazilian intensive care units: a prospective multicenter study. Intensive Care Med 1996; 22:564-70.

15. Lefering R, Zart M, Neugebauer E. Retrospective evaluation of the simplified Therapeutic Intervention Scoring System (TISS-28) in a surgical intensive care unit. Intensive Care Med. 2000;13(5):1794-802.

16. Ducci JA, Padilha KG, Telles SCR, Gutierrez BA. Gravidade de pacientes e demanda de trabalho de Enfermagem em Unidade de Terapia Intensiva: Análise evolutiva segundo o TISS-28. Rev Bras Ter Intensiva 2004; 16(1):22-7.

Received: Oct. $17^{\text {th }} 2008$

Accepted: Sep. $3^{\text {rd }} 2009$ 